\title{
The System of Social Support and Social Services in the Republic of Tatarstan
}

\author{
Maksimov D.S. a \\ Maximova M.N. $b$ \\ Mishakin T.S.c \\ ab Kazan State Medical University, Department of Economic Theory and Social Work, Kazan, 420055, Russia \\ c Kazan Federal University, Institute of Management, Economics and Finance, Kazan, 420008, Russia
}

Doi:10.5901/mjss.2015.v6n1s3p386

\begin{abstract}
This article analyzes the social services provided to certain categories of citizens of the Republic of Tatarstan aimed to improve the level and quality of their life, to increase their income through the system of social support.
\end{abstract}

Keywords: system of social services; recipients of services; social support; social services; accessible environment.

Social support to citizens is one of the sources to increase the income of the population. The Republic of Tatarstan implements social support of citizens in accordance to the federal laws about veterans, social protection of disabled people in the Russian Federation, targeted social support of the population in the Republic of Tatarstan and other normative legal acts of the Russian Federation and the Republic of Tatarstan.

Social support is provided by categorical principle (war and labor veterans, victims of political repression, rehabilitated and awarded citizens of the Republic of Tatarstan; soldiers and their families, disabled people, orphans, retired people) and address principle (families with children whose average per capita income is below the subsistence minimum established in the Republic of Tatarstan; citizens whose expenses for housing and communal services exceed an amount corresponding to the maximum allowable fraction of the cost of citizens to pay for utility services in total family income, according to the regional standards) principles.

Recipients of social support in the Republic of Tatarstan are veterans of labor; rear workers; rehabilitated citizens who suffered from political repression; retired people; children from large families; orphans, children left without parental care; recipients of subsidies for housing and utility services; awarded citizens; child support for families with incomes below the poverty level; federal benefit recipients; certain categories of citizens who work and live in rural areas; conscripts who receive a lump sum benefit for a birth of a child; conscripts who receive monthly benefit for the birth of a child; recipients of the compensation on parental preschools fee; citizens who receive care allowance of up to 1.5 years child; citizens who receive targeted subsidies "Tatteplosbyt."

The total amount of benefits is more than $\$ 11$ billion rubles per year.

The total number of recipients of state social support provided through the social security authorities in August 1st, 2014 was 1.58 million people, 350 thousand of them assigned to the federal level of responsibility.

The population gets social support for housing and communal services. The government spent 937.2 million rubles on subsidies for housing services for 7 months in 2014. 309,040 people from 140,301 families received this subsidy. Databases for payments for address housing and utility subsidies were formed In 2003, they include 1,218,176 households; 768.6 thousand beneficiaries; 425, 7 thousand recipients of grants et al.

The subsidies for the purchase of property are still being provided. 18092 of 18529 veterans assigned as in need of better housing conditions received this subsidy, including 233 veterans who received it in 2014.

Social support system established in the republic is constantly being improved by introducing additional ways of social support of certain categories of citizens.

Well-timed and reliable information plays huge role in proper organization of adequate social support of the population. The number of objective factors emerged in the industry of social protection of the Republic of Tatarstan urgently requires changes in the information processing technology, namely:

- the need to reduce the time spent on information processing while it was increasing;

- $\quad$ high intensity of the updating regulatory information; 
- improvement of accounting systems of most vulnerable segments of the population (targeted protection);

- the need for diverse, differentiated information and analytical base;

- monitoring, targeting of money spent on social support;

- analysis of socio-economic status and dynamics;

- development of the State Target Programs;

- efficient execution of new complex functions by the social protection of the population;

- ever-increasing requirements for employees of social protection in their professionalism, productivity, quality of work;

- the need to reduce staff turnover;

- the need to raise the prestige of the profession.

The databank of the targeted social protection in the Republic of Tatarstan includes the following information: pensions; disability; the amount of monthly payments; the presence of the federal categories; the amount of charges for public utility services; tariffs, regulations.

Functioning system allows you to interact with a number of ministries and agencies, service providers through the application of modern information technology. The number of participants of the interaction increases every year. Today more than 700 organizations are involved in the information exchange, including territorial social welfare agencies, suppliers of housing and communal services (TTG, Tatenergo, HOA, HBC, Vodokanal), the Department of Pension Fund of the Russian Federation in the Republic of Tatarstan, Department of Social Insurance Fund of the Russian Federation in the Republic of Tatarstan, Mandatory Health Insurance Fund Ministry of Health of Tatarstan, Ministry of Healthcare of the Republic of Tatarstan, the Civil Registry Office, branches of the Rosreestr, employment centers, preschools, and other lending institutions.

The suppliers of Rehabilitation equipment, guardianship authorities, Office of Education in municipalities of the Republic of Tatarstan, educational institutions of primary and secondary vocational education, service delivery of social benefits to citizens at home became the new participants in the information process during the last year.

The involvement of an increasing number of organizations and agencies in information technology enabled to organize optimally the process of providing social support, to eliminate the need for immediate treatment of the citizens in the organization, to reduce the number of multiple circulations of citizens to the social welfare agencies, to determine timely and reasonably the size of welfare payments ${ }^{1}$.

The mechanism of interaction of territorial agencies of social protection with the banks in terms of population receiving applications for the appointment of the individual social support (monthly travel payments for retired people, subsidies, benefits for retired people to pay for utility service) was introduced.

Now, if citizen opens a bank account, he has the ability to simultaneously file an application for the appointment of social support. Embedded interaction mechanism reduces the number of complaints of citizens, thus saving their time and reducing the order.

Therefore, social protection institutions, firstly, should actively cooperate with banks, thereby reducing the number of potential visitors to institutions of social protection; secondly, they need to intensify advocacy and outreach work with the population.

The needs of people, life changes require the introduction of additional ways of social support to certain categories of citizens ${ }^{2}$.

Additional benefit to families with children attending pre-school educational institutions was introduced on the $1^{\text {st }}$ of January, 2014. Additional compensation of the parental fees for supervision and care for the child in preschool educational institutions was set at the municipal level. Only parents whose average income is less than 20000 rubles per month can receive this benefit. As of 01.08 .2014 this compensation was paid to 62,959 children.

In the framework of the national program for children in difficult situations 4,840 vouchers in health camps and 4,550 vouchers to spa facilities were purchased in 2014.

For effective and quality services to disabled people the interagency agreement on information exchange between social ministries was signed. The mechanism for automated distribution of vouchers for spa treatment for recipients with

\footnotetext{
${ }_{1}^{1}$ Maximova MN, NV Butaeva Potential of information technology in the provision of social protection institutions // Bulletin of Kazan Technological University: T. 16. № 24; $M$ of the image. and Science of Russia, Kazan. nat. issled. tehnol. Univ. - Kazan: Publishing house KNRTU, 2013. - 328 p. (Pp 210-216).

2 Maximova MN, Shafigullin AR Targeting areas of labor services, employment and social protection (for example, the Republic of Tatarstan). - In the book Economic studies: analysis of the status and prospects of development: Monograph /, ed. Ed. prof. VA Katunina. - Book 30 - Moscow: Science: Inform; Voronezh: SGMP, 2013. - 208 p. (Pp 118-129). 
health problems was introduced in 2014 to eliminate corruption. Development of the program for automated distribution of vouchers to retired people and employees of public institutions of the Republic of Tatarstan is scheduled for 2015.

Current condition of social services system in the Republic of Tatarstan is characterized by positive changes in the management of the quality of public social services. The quality standards for the provision of public services were adopted in the Republic of Tatarstan. These standards establish uniform requirements for the procedure, the conditions and the quality of provision of social services in the Republic of Tatarstan. It determined the possibility of attracting nonprofit and commercial organizations to the public provision of social services. Currently, the state order for the provision of social services to the citizens of the Republic of Tatarstan by NGOs is located in three cities: Nizhnekamsk, Naberezhnye Chelny, Kazan.

Since 2013, the Ministry of Labor, Employment and Social Protection of the Republic of Tatarstan has introduced the electronic-queue in the customer service department of social protection of the city of Kazan and the major cities of the country. Pre-registration for the current day and the next seven days in the terminal electronic-queue was implemented.

The introduction of the registered coupons in terminals in electronic-queue is planned. It is possible to make an appointment by phone.

Another one innovation is an organization of citizens alert by SMS, or by other means, such as by e-mail. Today, such a mechanism is already being used to inform people with disabilities about the terms of their technical rehabilitation equipment.

133 public institutions function in the system of social services for the population of the Republic of Tatarstan. The level of social guarantees of security of the population of the Republic of Tatarstan in nursing home for elderly and disabled people, in orphanages, in boarding schools for mentally retarded children, institutions for minors, social service centers, centers of social assistance to families and children is $100 \%$, in neuropsychiatric boarding it is $88 \%$, in social adaptation center for homeless it is $81 \%$, in rehabilitation centers for disabled people it is $40 \%$, in rehabilitation centers for children and youth with disabilities it is $88 \%$.

In the first half of 2014, about 150 thousand people received the services in the social service institutions. The veterans of The Great Patriotic War (GPW) get special treatment. In the first half of 2014 the department of domestic social service served 4143 GPW veterans. 236 GPW veterans live in the institutions of social service.

The conditions for the effective functioning of the interagency system working with families at social risk, for the prevention of child and family trouble, for the prevention of child abandonment, neglect and juvenile delinquency were created in the Tatarstan Republic. The state system of prevention of child neglect and juvenile delinquency, which is based on close interagency cooperation between enforcement agencies and public healthcare, education agencies, commissions for minors and protection of their rights, the guardianship authorities, other governmental and nongovernmental organizations was created and is still functioning.

The key objectives and activities in the field of protection of children's rights are defined in the Republican strategy of Action for Children for 2013-2017. The strategy involves the organization of work for the early detection of family troubles and support to families in difficult situations, prevention of child abandonment, access to quality education, cultural development, and information security of the younger generation, promotion of healthy lifestyles, creating a system of protecting and promoting the rights and interests of children.

As a result of work carried out in the Republic of Tatarstan, we can see a decrease in the proportion of street children in the child population of the Republic of Tatarstan: $2010-0.78 \%, 2011-0.66 \%, 2012-0.59 \%, 2013-$ $0.41 \%$, the 1 st half of $2014-0.39 \%$.

In recent years, the number of families who are on the interagency patronage is reducing.

Currently the system of informing citizens about the purpose, the justified suspension of welfare payments by sending them text messages or other selected way is being tested now. Thus, timely information to the public would eliminate the additional treatment of citizens in social welfare agencies.

Currently, the Ministry of Information and Communications, the Ministry of Labor, Employment and Social Protection and the Ministry of Healthcare implemented in full integration of automated information system called "targeted social assistance" using the automated information system called "Republican Clinical Oncology Center." It allows people to assign compensation for travel expenses for transport to the place of treatment to citizens suffering from cancer, during the period of the application without presenting their certificates on passage of the treatment at the National Clinical Oncology Center.

At the same time it did not happen with the population suffering from chronic renal failure. The reasons for this are not only technical, but also organizational: the most medical organizations engaged in outpatient treatment by hemodialysis are commercial. They refused to participate in the exchange. Perhaps it would be appropriate to 
recommend colleagues from the Ministry of Health to mandate suppliers to provide information in electronic form before signing contracts.

Authorities are still working on the level and quality of life of disabled people.

Over the past twenty years the number of children with disabilities in the Russian Federation significantly increased and passed for half a million. In Russia, in 1995 the number of disabled children was 453.7 thousand people, in 2006 it increased to 557 thousand people, in 2013 it was 568,000 people. It is predicted that this number will exceed one million in the next ten years. According to WHO the number of children with disabilities from childhood is $2-3 \%$ of the total population in developed countries ${ }^{3}$. In our country, this percentage is slightly lower, but this does not mean that there are less children with disabilities. According to various subjective and objective reasons, they are not all on the account. In Tatarstan the category of "child with a disability" is set in 2013 for 13,987 people.

320,800 people classified as disabled live in the Republic of Tatarstan, 14.500 of them are children, 67000 of them are employed. From year to year the number of people with disabilities is not significantly reduced.

Within the framework of the state program called "Promotion of Employment of the Republic of Tatarstan for 20142020" the subroutine called "Implementation of measures to promote employment and the regulation of labor migration for 2014-2020" was developed, one of its tasks is to promote employment of parents raising children with disabilities and parents of many children.

Employment assistance to parents raising children with disabilities, and parents of many children was formed in previous years. So, due to co-financing from the federal budget, the conditions for employment of 292 parents raising children with disabilities were created.

Basically, jobs were created in the garment industry, security systems, advertising industry, in the system of housing and communal services, in the provision of public services (hair salons, photocopying equipment repair, sewing and mending, etc.).

Within the framework of the state program "Promotion of Employment of the Republic of Tatarstan for 2014-2020" it is planned to stimulate the employment of women with young children and children with disabilities, through the establishment (or providing equipment) of special jobs. The program is designed for 7 years, and for each year of the program it is planned to promote the employment of parents with children with disabilities and parents of many children in the amount of 29 people in Tatarstan.

The amount of funds to promote the employment of parents with disabled children, and parents of many children for 2014-2020, will be 10150.0 thousand rubles at the rate of 1450.0 thousand rubles per year. Thus, the reimbursement of costs to the employer to create a workplace for parents with disabled children and parents of many children will be 50.0 thousand rubles.

The system of providing social support to disabled people, of creating a barrier-free environment conditions for disabled people and other people with limited mobility is clearly built and worked out. In order to implement the state policy towards disabled people the Concept of development of disability prevention and rehabilitation of disabled people was adopted in the Republic of Tatarstan.

In 2011, the Republic of Tatarstan became a participant of the two-year pilot project to create the conditions of availability. The work was carried out in all 45 municipalities and urban districts of the Republic, in which 178 objects were adapted. The municipal program "Accessible Environment" was developed in every region of the Republic. This program designed: the working groups to conduct certification of the objects according to their accessibility; the expert groups of the representatives of public organizations of disabled people who received certificates; councils for the disabled people under the heads of municipalities.

In the framework of the "Accessible Environment" program the software for creating and developing a data bank and card availability of social, transport and engineering infrastructure for people with limited mobility was developed and launched into production. Also The Accessibility Map with all the social, administrative, cultural and other objects on it was created for disabled people of different groups. The certification of the social infrastructure in all municipalities of the republic is being done now. On the state of $08 / 28 / 2014$ there is information on the 3,983 objects availability on the map. Since 06/25/2014 the ability to track usage statistics of the Republican interactive map availability of facilities for people with limited mobility is installed (293 users during the period from 25/06/2014 to 08/29/2014).

Web pages "Accessible Environment" are opened on the official websites of ministries the Republic of Tatarstan where users can find regulatory framework, guidelines on the formation of the available infrastructure, developed by the Ministry of Labor, Employment and Social Protection of the Republic of Tatarstan, the information about the availability of subordinate objects, etc.

${ }^{3}$ Children with disabilities - children with disabilities in 2014. World Health Organization: [electronic resource] URL: http://www.who.int/ru. 
In 2014, the adaptation is performed on 131 objects, including 33 health care facilities; 46 objects of social protection and employment; 21 cultural objects; 18 objects of physical culture and sports; in the building of the Ministry of Construction, Architecture and Housing and Communal Services of the Republic of Tatarstan; 12 institutions of vocational education; pedestrian crossings in 16 municipalities.

Under an agreement between the Government of the Republic of Tatarstan and the Ministry of Education and Science of the Russian Federation the adaptation of 104 educational institutions (including 15 correctional schools) will be held in 2014.

Within the framework of the project "Open Tatarstan" on the Website of state and municipal services, the project "People's control" is being implemented. The "Accessible Environment" section is created there allowing the user to leave a notice on availability of an object and to evaluate the quality of decision making by state or municipal authorities.

Thus, the system of social support and social services in the Republic of Tatarstan is constantly updated with new services with improved quality, and continued stability in service provision. To the satisfaction of the population it may be noted that every year brings new social benefits. This in turn leads to a stable an average increase of $3.6 \%$. of the number of recipients: The Republic Bank for Social Security contains information about 3.5 million people and almost all households in the Republic $(1,325,616)$. 1.6 million people receive more than 70 kinds of public services provided by the social security monthly.

\section{References}

Maksimov MN, NV Butaev Potential of information technology in the provision of social protection institutions // Bulletin of Kazan Technological University: T. 16. № 24; $\mathrm{M}$ of the image. and Science of Russia, Kazan. nat. issled. tehnol. Univ. - Kazan: Publishing house KNRTU, 2013. - 328 p. (Pp 210-216).

Maximov MN, Shafigullin AR Targeting areas of labor services, employment and social protection (for example, the Republic of Tatarstan). - In the book Economic studies: analysis of the status and prospects of development: Monograph /, ed. Ed. prof. VA Katunina. - Book 30 - Moscow: Science: Inform; Voronezh: SGMP, 2013. - 208 p. (Pp 118-129).

Panasyuk, M.V., Pudovik, E.M., Malganova, I.G. (2014). Modified index method in scenarios of regional socio-economic development. Mediterranean Journal of Social Sciences, 5 (18 SPEC. ISSUE), pp. 331-334.

www.mtsz.tatar.ru - Ministry of Labour, Employment and Social Protection of the Republic of Tatarstan.

The number of disabled children up to 18 years in the Russian Federation. Federal State Statistics Service: [electronic resource] URL: http://www.gks.ru.

The World Report on Disability. June 9, 2012. World Health Organization: [electronic resource] URL: http://www.who.int/ru.

Information on the results of PKU "GB ITU" for the Republic of Tatarstan for 2013. Federal Governmental Institution "The head office of medical and social examination of the Republic of Tatarstan: [electronic resource] URL: http://mse16.ru/statistika.

State program "Promotion of Employment of the Republic of Tatarstan for 2014-2020" // Ministry of Labour Employment and Social Protection of the Republic of Tatarstan // [electronic resource] URL: http://mtsz.tatarstan.ru.

Shigabieva A.M., Safiullin L.N., Mazitov V.M., Saipullaev U.A. Some methodological foundation of an innovation theory. Life Science Journal 2014; 11(6s): $388-391$.

Khairullov, D.S., Saipullaev, U.A. (2014). Management of social and economic security of the region. Mediterranean Journal of Social Sciences, 5 (12), pp. 177-182. 